\title{
Distal Phalanx of Foot
}

National Cancer Institute

\section{Source}

National Cancer Institute. Distal Phalanx of Foot. NCI Thesaurus. Code C52783.

The five bones that form the tips of the toes. 